\title{
Indoor Environmental Quality in Latin American Buildings: A Systematic Literature Review
}

\author{
Claudia Valderrama-Ulloa ${ }^{1, *(\mathbb{D})}$, Lorena Silva-Castillo ${ }^{1}$, Catalina Sandoval-Grandi ${ }^{2}$, \\ Carlos Robles-Calderon ${ }^{1}$ and Fabien Rouault ${ }^{1}$ (D) \\ 1 School of Civil Construction, Pontificia Universidad Católica de Chile, Av. Libertador Bernardo O’Higgins \\ 340, 8331150 Santiago, Chile; ldsilva1@uc.cl (L.S.-C.); cerobles@uc.cl (C.R.-C.); frouault@uc.cl (F.R.) \\ 2 School of Engineering, Pontificia Universidad Católica de Chile, Av. Libertador Bernardo O'Higgins 340, \\ 8331150 Santiago, Chile; cpsandoval@uc.cl \\ * Correspondence: c.valderrama@uc.cl; Tel.: +56-22-3547065
}

Received: 29 November 2019; Accepted: 13 January 2020; Published: 15 January 2020

\begin{abstract}
The amount of time people spend inside buildings is significant. Indoor environment quality deficiencies in some of these buildings may affect the health of its users. Therefore, a systematic literature review has been conducted to assess the quality of indoor environments in existing buildings in Latin America. The objectives of this review are (1) identifying countries and building types whose indoor environment quality has been analyzed the most, (2) identifying most used evaluation strategies, (3) identifying comfort types and most evaluated variables, and (4) determining whether or not Latin American buildings are comfortable and what local factors contribute to that effect. From the 100 selected papers for this analysis, it was noted that Brazil and Argentina led the studies on residences and schools. It was also noted that hygrothermal comfort was the most analyzed comfort type, with temperature and humidity leading the number of studies. Finally, this review shows a lack of studies including buildings whose users are sensitive to indoor environmental quality, such as nurseries, senior homes, or health facilities. Additionally, there is a sustained discrepancy between objective measuring methods and user perception. Furthermore, a detailed analysis of 88 buildings shows that in Latin America, $67.5 \%$ of buildings are uncomfortable; thus, it is necessary to improve the designs and regulatory standards, to educate users, and to improve building monitoring management at the operational stage.
\end{abstract}

Keywords: hygrothermal comfort; indoor air quality; acoustic comfort; visual comfort

\section{Introduction}

The increase in the number of time people spend inside buildings is significant. Both architects and engineers must think of ways to improve environmental comfort for users and, at the same time, improve energy performance in buildings. Comfort is, in fact, important since people spend around $80 \%$ to $90 \%$ of their days inside buildings [1]. Hence, it is relevant to study indoor environment quality in different building types.

Buildings affect people's health. There have been reports of diseases related to building use, the most relevant of which is sick building syndrome. Sick building syndrome is a term applied to buildings whose occupants experience physical discomfort just by being in them. It also describes the symptoms that show up after spending a certain number of hours in an enclosed space. These symptoms include eye, nose, and throat irritation, headaches, skin rashes, and respiratory problems. This term was born in the early 1980s when the first energy problems began worldwide. As a result, buildings became more hermetic, ventilation was reduced and, therefore, diseases started to spread [2]. 
Moreover, low-quality lighting can cause eye irritation and headaches; noise levels over $50 \mathrm{dBA}$ can increase headaches and reduce concentration on tasks [3]. Inappropriate or excessive use of air conditioning (changing comfort temperature or humidity levels) can cause, on low levels, irritation, pain, and an increase of infections. On high levels, it can foster the growth of fungi in the air [4]. If this environment is dry, respiratory diseases will increase. Health consequences have been quantified in terms of deaths. Annually, 4.3 million people die prematurely due to diseases attributable to indoor air contamination caused by using inefficient solid fuels for cooking (data for 2012). Main causes of death are $12 \%$ pneumonia, $34 \%$ strokes, $26 \%$ ischemic cardiopathology, $22 \%$ chronic obstructive pulmonary disease, and $6 \%$ are due to lung cancer [5].

Finally, besides having significant effects on people's health, it is important to mention that indoor environment quality also affects people's productivity at work. When assessing instruments to measure the loss of productivity at work, Meerding et al. [6] found that reduced productivity due to health problems was predominant in $5-12 \%$ of workers, with a mean productivity loss of $12-28 \%$. For example, ventilation and temperature-humidity are associated with absenteeism rates. Furthermore, as Collins et al. [7] point out, it is possible to estimate that by doubling the ventilation rate, absenteeism at work would decrease from $2 \%$ ( $5 \mathrm{~d}$ per year) to $1.5 \%$ (an average of $3.8 \mathrm{~d}$ per year). Regarding temperature, Seppänen et al. [8] showed that for every Celsius degree increase in temperature (on a 25 ${ }^{\circ} \mathrm{C}$ to $32{ }^{\circ} \mathrm{C}$ range), there was a $2 \%$ reduction of employee performance. No differences were found in the $21-25^{\circ} \mathrm{C}$ range.

Several studies show the direct connection between indoor environmental quality (IEQ) and energy performance in buildings. Providing and maintaining acceptable energy cost levels and low carbon emissions require building designers, clients, and users to find the right balance between energy savings and comfort $[9,10]$. However, good IEQ is fundamental for the wellbeing and good performance of its occupants [11]. Some of the studies from the last decade such as those of [12,13] or [14] deal with thermal comfort and its adaptive models, or ventilation rates and its relation to health [15]. Furthermore, there is interesting research on energy use and the wellbeing of its occupants [16].

There are also article reviews on building evaluations in actual use conditions (post-occupancy evaluation, POE) and the performance of one of the variables of indoor environment quality [17], or as a supplement to management systems for buildings in use to improve any variable of indoor environment quality, thus enhancing energy efficiency [18]. Additionally, some reviews focus on specific building types, such as schools $[19,20]$, and how student health is affected by factors related to indoor environment quality [21], or the connection between IEQ and energy performance [22]. It is also possible to find literature reviews on historic buildings [23] and office buildings [24].

Previous reviews have dealt with the topic of our current review. However, as we will point out below, they have not focused on Latin America and have not considered all the factors or indexes for indoor environment quality that the present review has included.

Traditionally, comfort has been studied from the perspective of the physical environment and the physiology of its occupant, mainly in terms of four factors: hygrothermal comfort, acoustic comfort, indoor air quality (IAQ), and visual comfort [25]. These factors are studied through different interconnected elements that are difficult to estimate, mainly because of the absence of set protocols for measurement recollection (both objective and subjective) and the number of variables to be considered [26]. Thus, comfort is understood as a set of environmental conditions accepted by individuals for carrying out their regular activities [27]. Consequently, hygrothermal comfort must ensure that an individual does not experience too much cold or heat. Therefore, temperature, humidity, and airflow must be kept within the acceptable range. Visual comfort must guarantee enough light for individuals and their activities through appropriate quality and balance. Also, it must provide good outside views. Acoustic comfort entails having an adequate noise level and quality to use the space as it was intended [26]. Finally, IAQ is necessary to improve sensory perception. In turn, it propitiates a clean environment in terms of pollutant emissions such as carbon dioxide $\left(\mathrm{CO}_{2}\right)$, particulate matter (PM), or other pollutants. 
Therefore, it is of utmost importance to measure and grade indoor environment quality on buildings in use. Such analysis would allow to rectify building management in their operational stage and apply to future designs what previous experiences have taught us. On the other hand, since the wellbeing of users in existing buildings depends on the quality of the construction and local regulation standards, this study undertakes a systematic review of current literature to identify what types of comfort are measured in Latin America, their parameters, building type, and evaluation strategy. With this data, we will try to conclude whether or not Latin American buildings are comfortable. These results will provide updated information to researchers on indoor environment quality in Latin America, thus allowing new research efforts in the field.

\section{Materials and Methods}

This review followed the Preferred Reporting Items for Systematic Reviews and Meta-Analyses (PRISMA) checklist 2009 methodology [28]. Indexed 2018 publications found on Google Scholar, Scopus, Scielo, and Latindex were consulted. Additionally, other publications of interest found on Researchgate were included.

In total, 256 results were obtained from each database as follows: Scopus 113, Scielo 15, and Latindex 38. There were over 213,000 results on Google Scholar. Therefore, we only reviewed the first 20 result pages. Thus, we reached a total of 72 additional ones, the majority of which were peer-reviewed conference papers. Finally, Researchgate provided 18 results.

The articles were reviewed by the authors, taking into consideration studies complying with the criteria defined by the authors (Table 1). The inclusion criteria were (1) objective or subjective collection of information, (2) presence of quantitative and qualitative studies, (3) measurements done to buildings in Latin America, (4) analyzed building typology—housing, School, office buildings, university buildings, and government buildings, (5) papers published between 2008 and 2017, (6) papers written in English, Spanish, and Portuguese, (7) papers published in peer-reviewed journals, and (8) peer-reviewed conference papers.

Table 1. Keywords used in the search. Source: Authors.

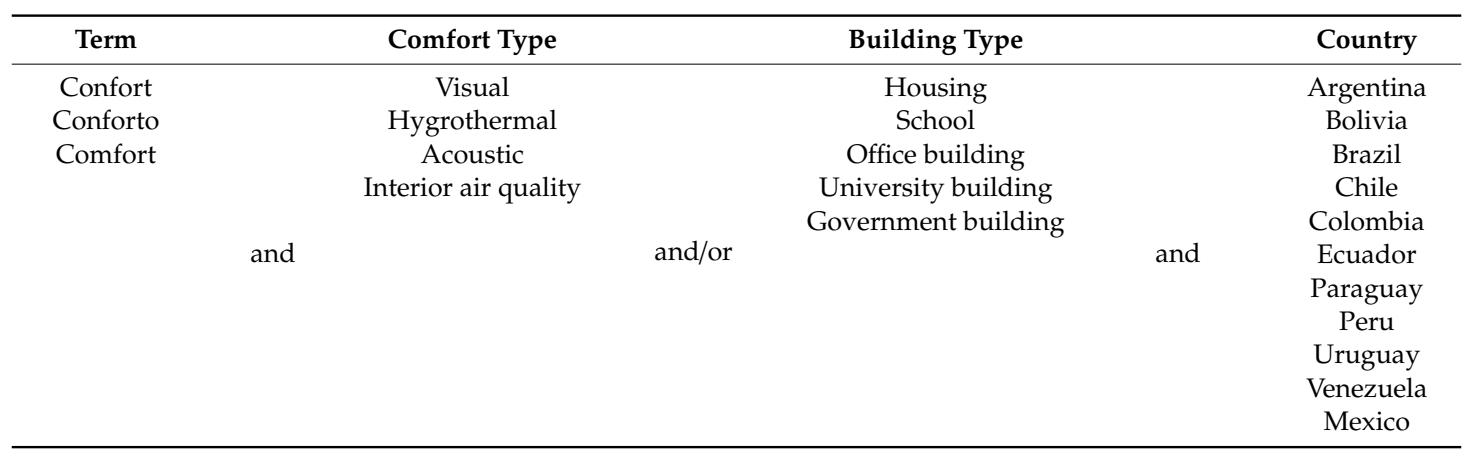

The exclusion criteria were (1) papers including just simulations (these papers were considered if they had some objective or subjective measurements), and (2) the case study building must exist, or at least a prototype, allowing for the simulation of use conditions. Figure 1 shows a PRISMA flowchart. After the identification, screening, and eligibility stages, 100 papers were included in the qualitative analysis and 88 in the quantitative analysis. 


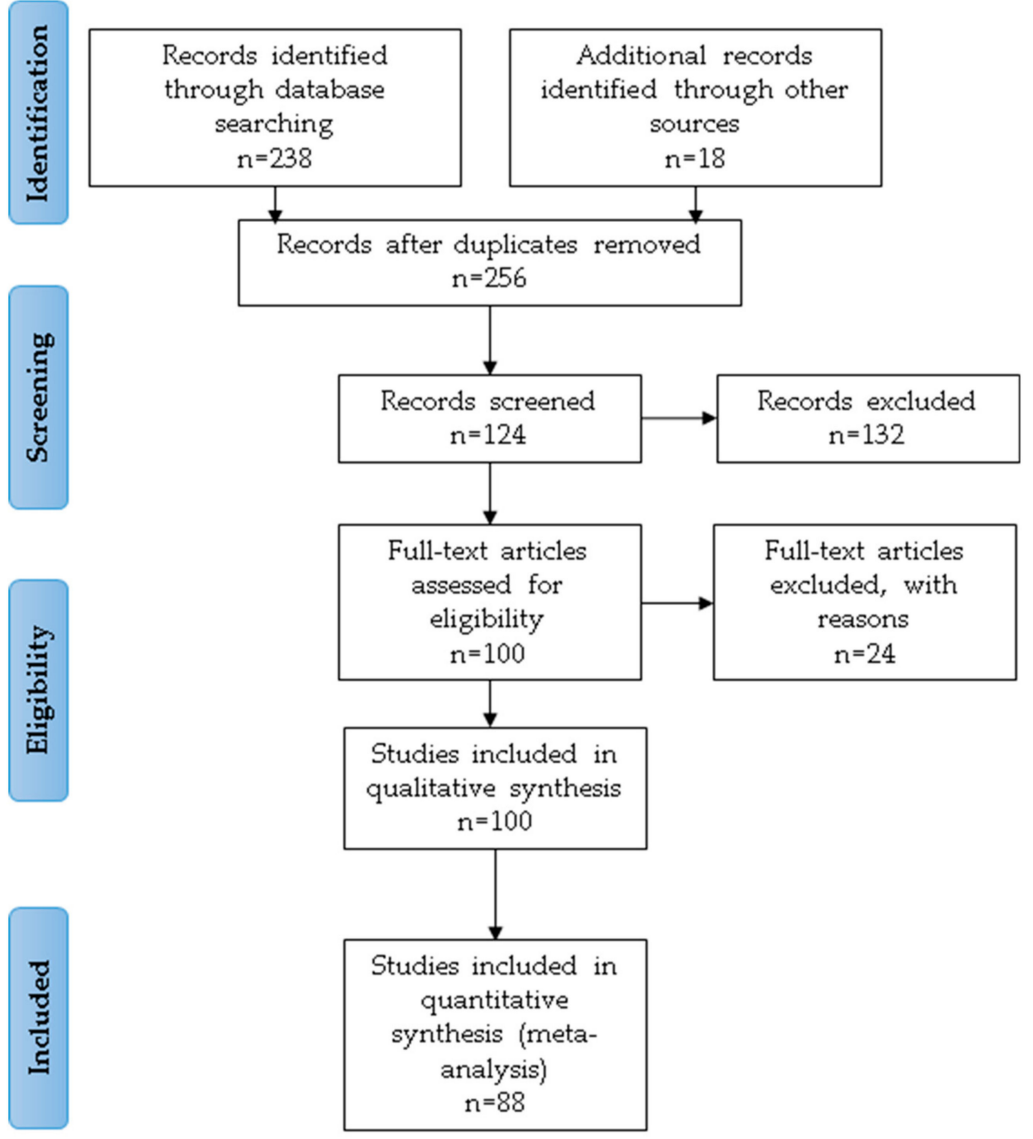

Figure 1. The Preferred Reporting Items for Systematic Reviews and Meta-Analyses (PRISMA) flowchart of literature search and review. Source: By Authors based on PRISMA 2009 [28].

\subsection{Paper Selection and Classification}

For this study, we compiled information from papers focusing on indoor environment quality variables affecting the relationship between human beings and the building interiors they use or inhabit. We reduced the span of papers to those concerning the Latin America region. We took into consideration information regarding real data from tools that measured the variables that affect IEQ. Surveys evaluating the same variables were considered as well. All data comparing wellbeing inside existing buildings by means of computer tools or statistical calculations were disregarded as they do not provide an approximation on how buildings behave in real-time.

\subsection{Analysis by Variable Type}

After classification, a variable comparison was performed. To this end, graphs were used to contrast results and to try and determine whether there were distribution trends in countries carrying out this type of research. Specifically, what building types, which in situ evaluation strategies were used when studying this phenomenon, and what comfort type and variables were most researched were investigated.

Thus, for hygrothermal comfort, we looked for variables such as relative humidity, dry bulb temperature, indoor and outdoor temperature, and air velocity. For visual comfort, natural and artificial lighting of spaces were determined. Likewise, for acoustic comfort, reverberation and ambient noise were considered. For IAQ, ventilation rates and emission of polluting gases such as $\mathrm{CO}_{2}, \mathrm{PM}$, or other were identified. 


\subsection{Paper Selection Based on IEQ Most Recurrent Variables}

From the most recurrent variables for comfort evaluation in existing buildings, conclusions were drawn on whether or not buildings in Latin America were comfortable, what the reasons were behind it, and which variables affected or contributed to the wellbeing of Latin Americans. The analyses, results, and discussions of the 100 papers considered for this review are shown in Table 2.

Table 2. Included literature in the systematic review $(n=100)$. Source: By Authors.

\begin{tabular}{|c|c|c|c|c|c|c|c|c|c|c|c|c|}
\hline \multirow{2}{*}{ Reference } & \multirow{2}{*}{ Year } & \multirow{2}{*}{ Country } & \multirow{2}{*}{$\begin{array}{c}\text { Building } \\
\text { Type }\end{array}$} & \multicolumn{4}{|c|}{ Comfort Type $^{1}$} & \multicolumn{5}{|c|}{ Assessment Strategies $^{2}$} \\
\hline & & & & $\mathbf{H}$ & $\mathrm{V}$ & I & Ac & $\mathbf{R}$ & O & $\mathbf{S}$ & C & $\mathrm{Au}$ \\
\hline Adiane-Borges et al. [29] & 2016 & Brazil & $\begin{array}{l}\text { University } \\
\text { buildings }\end{array}$ & $\mathrm{x}$ & & $x$ & & $\mathrm{x}$ & & $\mathrm{x}$ & & \\
\hline Akustsu et al. [30] & 2013 & Brazil & School & $\mathrm{x}$ & & & & & & $\mathrm{x}$ & & \\
\hline Alías et al. [31] & 2010 & Argentina & Housing & $\mathrm{x}$ & & & & $\mathrm{x}$ & & $x$ & & \\
\hline Alonso-Frank, Kuchen, Toranzo [32] & 2012 & Argentina & $\begin{array}{l}\text { University } \\
\text { buildings }\end{array}$ & $\mathrm{x}$ & & & & & & $\mathrm{x}$ & & \\
\hline Alves et al. [34] & 2017 & Brazil & $\begin{array}{l}\text { University } \\
\text { buildings }\end{array}$ & & $x$ & $\mathrm{x}$ & & & & & & $x$ \\
\hline Alves, Duarte, Gonçalves [35] & 2016 & Brazil & Housing & & $\mathrm{x}$ & & & & $\mathrm{x}$ & & $\mathrm{x}$ & \\
\hline Armijo, Whitman, Casals [36] & 2010 & Chile & School & $\mathrm{x}$ & & & & $\mathrm{x}$ & & & & \\
\hline Biondi, Martini, Lima-Neto [40] & 2015 & Brazil & $\begin{array}{l}\text { University } \\
\text { buildings }\end{array}$ & $\mathrm{x}$ & $\mathrm{x}$ & & & $\mathrm{x}$ & & & $\mathrm{x}$ & $x$ \\
\hline Boutet et al. [41] & 2011 & Argentina & School & & & $\mathrm{x}$ & & & $\mathrm{x}$ & & & \\
\hline Boutet, Hernández, Jacobo [42] & 2013 & Argentina & School & $\mathrm{x}$ & & $\mathrm{x}$ & & & $\mathrm{x}$ & $\mathrm{x}$ & & \\
\hline Bravo, González [43] & 2013 & Venezuela & Housing & & $\mathrm{x}$ & & & & $\mathrm{x}$ & & & \\
\hline Bressane et al. [44] & 2009 & Brazil & $\begin{array}{l}\text { University } \\
\text { buildings }\end{array}$ & $\mathrm{x}$ & $\mathrm{x}$ & & & & $\mathrm{x}$ & & & \\
\hline Bustamante et al. [45] & 2012 & Chile & $\begin{array}{c}\text { Office } \\
\text { buildings }\end{array}$ & $\mathrm{x}$ & $\mathrm{x}$ & & & $\mathrm{x}$ & & & & \\
\hline Cisterna et al. [46] & 2015 & $\begin{array}{c}\text { Argentina/ } \\
\text { Brazil }\end{array}$ & School & $\mathrm{x}$ & $\mathrm{x}$ & & & $\mathrm{x}$ & $\mathrm{x}$ & $\mathrm{x}$ & & \\
\hline De Vecchi, Cândido, Lamberts [51] & 2016 & Brazil & $\begin{array}{l}\text { University } \\
\text { buildings }\end{array}$ & & & & $\mathrm{x}$ & $\mathrm{x}$ & & & & \\
\hline Delbene, Evans [52] & 2010 & Argentina & $\begin{array}{l}\text { University } \\
\text { buildings }\end{array}$ & $\mathrm{x}$ & & & & & $x$ & & & \\
\hline Esparza-López et al. [53] & 2012 & Mexico & Housing & & & & $x$ & & $\mathrm{x}$ & & & \\
\hline Esparza-López et al. [54] & 2012 & Mexico & Housing & $\mathrm{x}$ & $\mathrm{x}$ & & $\mathrm{x}$ & & & $\mathrm{x}$ & & \\
\hline Espinosa-Cancino, Cortés-Fuentes [55] & 2015 & Chile & Housing & $\mathrm{x}$ & $\mathrm{x}$ & & & & $\mathrm{x}$ & & & \\
\hline Fastofski, González, Kern [56] & 2017 & Brazil & Housing & $\mathrm{x}$ & $\mathrm{x}$ & & & & $\mathrm{x}$ & $\mathrm{x}$ & & \\
\hline Felippe, Kuhnen, Silveira [57] & 2016 & Brazil & School & & $\mathrm{x}$ & & & & & $\mathrm{x}$ & & \\
\hline Ferrón, Pattini, Lara [58] & 2010 & Argentina & $\begin{array}{c}\text { Office } \\
\text { buildings }\end{array}$ & & & $x$ & & & & $\mathrm{x}$ & & \\
\hline Ferrón, Pattini, Lara [59] & 2011 & $\begin{array}{c}\text { Argentina/ } \\
\text { Brazil }\end{array}$ & $\begin{array}{c}\text { Office } \\
\text { buildings }\end{array}$ & $x$ & & & & $\mathrm{x}$ & & & $\mathrm{x}$ & \\
\hline Filippín, Flores- Larsen, Marek [60] & 2015 & Argentina & $\begin{array}{c}\text { Office } \\
\text { buildings }\end{array}$ & & $\mathrm{x}$ & & & & $\mathrm{x}$ & $\mathrm{x}$ & & \\
\hline Filippín, Flores-Larsen [61] & 2012 & $\begin{array}{c}\text { Argentina/ } \\
\text { Brazil }\end{array}$ & Housing & $\mathrm{x}$ & & & & $\mathrm{x}$ & & & & \\
\hline Filippín, Flores-Larsen, Mercado [62] & 2011 & $\begin{array}{c}\text { Argentina/ } \\
\text { Brazil }\end{array}$ & Housing & $\mathrm{x}$ & & & & $\mathrm{x}$ & & $\mathrm{x}$ & & \\
\hline Filippín, Sipowicz, Flores-Larsen [63] & 2013 & Argentina & Housing & $\mathrm{x}$ & & & & $\mathrm{x}$ & & & & \\
\hline Follari, Filippín [64] & 2011 & Argentina & Housing & & & $\mathrm{x}$ & & & $\mathrm{x}$ & & & \\
\hline
\end{tabular}


Table 2. Cont

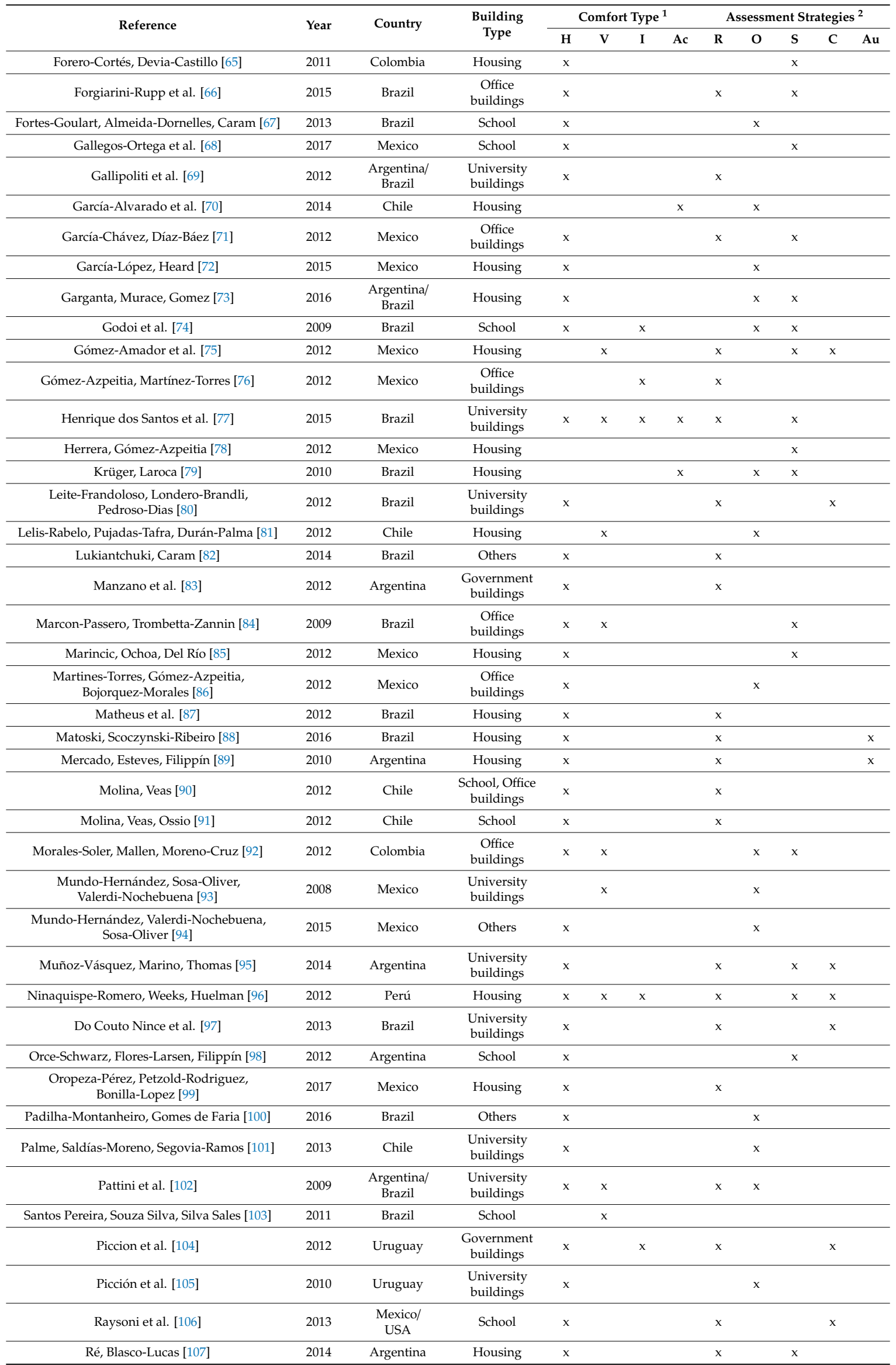


Table 2. Cont.

\begin{tabular}{|c|c|c|c|c|c|c|c|c|c|c|c|c|}
\hline \multirow{2}{*}{ Reference } & \multirow{2}{*}{ Year } & \multirow{2}{*}{ Country } & \multirow{2}{*}{$\begin{array}{l}\text { Building } \\
\text { Type }\end{array}$} & \multicolumn{4}{|c|}{ Comfort Type $^{1}$} & \multicolumn{5}{|c|}{ Assessment Strategies $^{2}$} \\
\hline & & & & $\mathbf{H}$ & $\mathrm{V}$ & I & Ac & $\mathbf{R}$ & $\mathbf{O}$ & S & $\mathrm{C}$ & $\mathrm{Au}$ \\
\hline Ré, Blasco-Lucas [108] & 2012 & Argentina & Housing & $\mathrm{x}$ & & & & $\mathrm{x}$ & & & & $\mathrm{x}$ \\
\hline Ré, Blasco-Lucas, Filippín [110] & 2016 & Argentina & School & $\mathrm{x}$ & & & & $\mathrm{x}$ & & $\mathrm{x}$ & & \\
\hline Ré, Blasco-Lucas, Filippín [111] & 2016 & Argentina & School & $\mathrm{x}$ & & & & $\mathrm{x}$ & & $\mathrm{x}$ & & \\
\hline Rodriguez, Pattini [112] & 2010 & Argentina & $\begin{array}{c}\text { Office } \\
\text { buildings }\end{array}$ & $\mathrm{x}$ & $\mathrm{x}$ & & & & & $\mathrm{x}$ & & \\
\hline Soto-Muñoz, Trebilcock, Pérez-Fargallo [113] & 2015 & Chile & School & $\mathrm{x}$ & & & & $\mathrm{x}$ & & & & \\
\hline Toranzo, Kuchen, Alonso [114] & 2012 & Argentina & $\begin{array}{l}\text { University } \\
\text { buildings }\end{array}$ & $\mathrm{x}$ & & & & $\mathrm{x}$ & & $\mathrm{x}$ & & \\
\hline Trebilcock et al. [115] & 2012 & Chile & School & $\mathrm{x}$ & & & & $\mathrm{x}$ & & $\mathrm{x}$ & & \\
\hline Trebilcock et al. [116] & 2016 & Chile & School & $\mathrm{x}$ & & & & & $\mathrm{x}$ & & & \\
\hline Vásquez, Prieto, Aguirre [121] & 2012 & Chile & $\begin{array}{c}\text { Office } \\
\text { buildings }\end{array}$ & & & & $\mathrm{x}$ & & $\mathrm{x}$ & & & \\
\hline Vasquez et al. [122] & 2013 & Chile & $\begin{array}{c}\text { Office } \\
\text { buildings }\end{array}$ & & & & $\mathrm{x}$ & & $\mathrm{x}$ & & & \\
\hline Viloria et al. [123] & 2016 & Colombia & School & $\mathrm{x}$ & & & & & $\mathrm{x}$ & & & \\
\hline Wegertseder, Trebilcock [124] & 2012 & Chile & Housing & $\mathrm{x}$ & & & & & $\mathrm{x}$ & & & \\
\hline Wrobel-Straub et al. [125] & 2017 & Brazil & $\begin{array}{l}\text { University } \\
\text { buildings }\end{array}$ & & & & $\mathrm{x}$ & & $\mathrm{x}$ & & & \\
\hline Zannin et al. [126] & 2013 & Brazil & $\begin{array}{l}\text { University } \\
\text { buildings }\end{array}$ & $\mathrm{x}$ & & & & & $\mathrm{x}$ & & & \\
\hline
\end{tabular}

\section{Results}

Analysis of selected papers has been divided into three parts: the first one shows the geographic distribution of IEQ research in Latin America and the building type considered. The second one analyzes the used in situ evaluation strategies to assess comfort levels in the case study. The third and final part analyzes the main variables for evaluating comfort levels inside the building. Likewise, we identified the main evaluation objectives of each study.

\subsection{Geographic Distribution and Studied Typologies}

As shown in Figure 2a, Argentina and Brazil were the Latin American countries who had done more research on IEQ, adding up to 59\% (22\% Argentina, 28\% Brazil, 9\% research done by both countries). Next was Chile, with $17 \%$ of the studies, and Mexico with $15 \%$. Colombia (5\%), Uruguay $(2 \%)$, and Peru and Venezuela (1\%) were the countries with the least amount of research on the subject.

Regarding building typology, housing was the most studied with $31 \%$ (see Figure $2 \mathrm{~b}$ ), followed by schools with $26 \%[30,68,90,98,115,116,123]$ or example, Felippe et al. [57] surveyed their students to identify the most important factors that they would like to have in their schools. IAQ (clean and ventilated) and lighting comfort were some of the highlighted categories. For university buildings (23\%), the study of Alves et al. [34] analyzed how thermal mass and natural ventilation affected thermal performance in old buildings and provided solutions for improving thermal performance in buildings with thermal inertia. In another study, Borges et al. [29] analyzed thermal performance using predictive mean vote (PMV) and predicted percentage of dissatisfaction (PPD) indexes. In the case of office buildings (15\%), a study conducted by Vasquez et al. [121] examined the performance of a group of offices built in Chile in the 1960s. Art galleries and hospitals were also analyzed (2\%). 


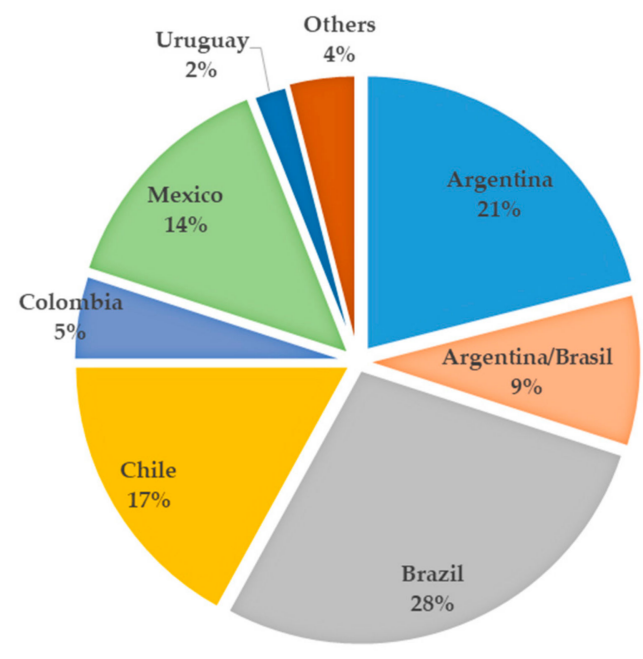

(a)



(b)

Figure 2. Publication distribution by (a) country and (b) building type. Source: By Authors.

Building typology distribution lacks certain categories whose users are sensitive to IEQ, such as nurseries, senior residences, or health buildings. The only study dealing with hospitals evaluated hygrothermal comfort in facilities in Brazil [82].

\subsection{Measuring Strategies}

On the subject of strategies used for the data collection on building indoor environment, researchers used different measuring tools, both individually and additively. For example, specific or constant objective measurements of one or more IEQ parameters, surveys, simulations, or audits were observed.

Some of the specific or constant objective measurements were air temperature, air velocity, humidity for hygrothermal comfort, illuminance for visual comfort, $\mathrm{CO}_{2}$ concentration, $\mathrm{CO}$ and total Particulate Matter (PMtot) for IAQ, and equivalent noise level for acoustic comfort, among others.

Surveys, as a subjective measuring tool, were mainly based on questionnaires in which the evaluation of different factors and general satisfaction levels were collected directly from the respondents' opinions. In the selected corpus, it was possible to find thermal satisfaction surveys $[38,43,44,47,51,54$, $55,66,72,80,85,86,90,100,114,117-119,122,123,125]$ or [104], visual satisfaction $[46,102,105,122]$ or [119], acoustic satisfaction, $[44,103,122]$ humidity sensation $[72,78]$, and air quality $[32,33,91]$. In general, there were five set satisfaction levels as well as preference levels. For example, in thermal satisfaction $[38,43$, $51,114,119]$, respondents were asked if they preferred a colder or warmer environment.

Some studies supplemented subjective-objective IEQ measurements with energy consumption measurements [33], energy simulations [69], or an audit consisting of thermal performance evaluation of the building's thermal envelope [56,109], or architectural design [114].

Figure 3 shows the paper distribution by the number of strategies combined to assess IEQ and provides a breakdown of evaluation strategies used. As shown in Figure 3, the majority of articles combined one or two strategies, the main of which were one-time measurements (39), real-time measurements (50), and surveys (40). Only two articles [47,80] included four of the five identified strategies. 


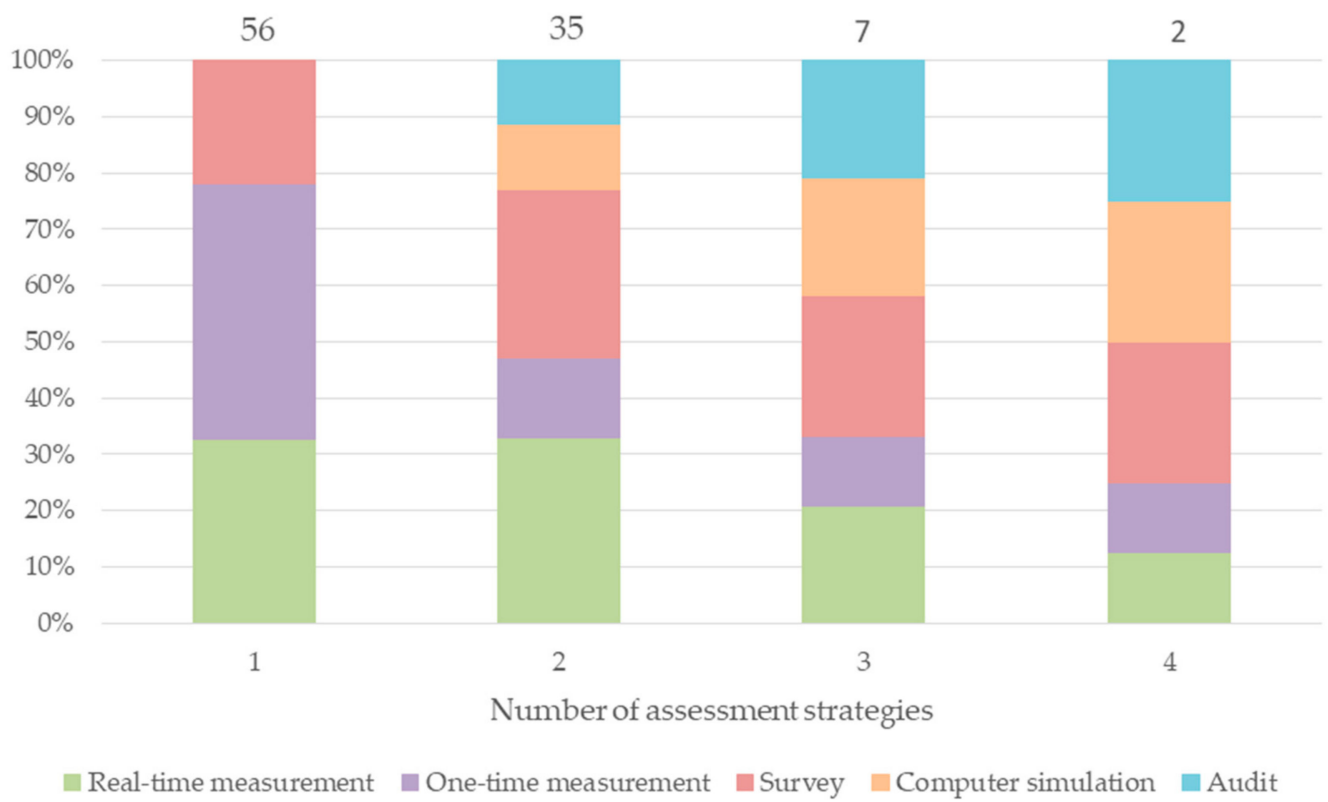

Figure 3. IEQ evaluation strategies distribution by the number of methods combined in the same paper. Source: By Authors.

\subsection{IEQ Factors Studied}

Some of the factors analyzed by several studies were physical parameters and survey results on the users' perceptions or preferences (Figure 4). Temperature (66 papers), relative humidity (31 papers), and illuminance ( 28 papers) were the parameters generally measured by sensors like the hobo U-12. In conditioned buildings, it is possible to consolidate temperature measurements, relative humidity, and air velocity via indexes like the predicted mean vote (PMV) or predicted percentage of dissatisfaction (PPD). These indexes are comparable to user survey results. Biondi et al. [40] suggest using the physiological equivalent temperature (PET) as a thermal comfort indicator, which unifies the temperature scale. It takes into consideration air temperature, radiative temperature, air velocity, and humidity equal to the PMV.

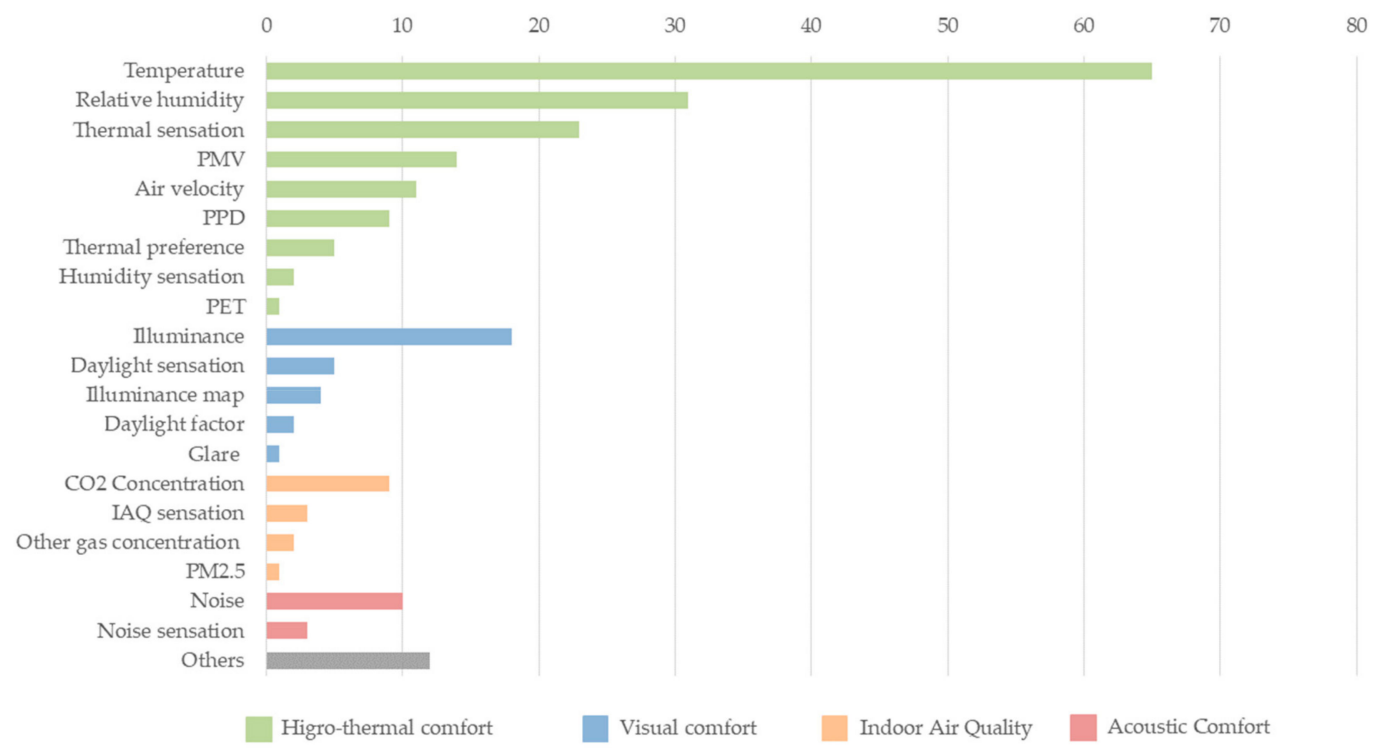

Figure 4. The occurrence of analyzed variables for each comfort type in selected papers. Source: By Authors. PMV: predicted mean vote; PPD: predicted percentage of dissatisfaction; PET: physiological equivalent temperature; PM2.5: particulate matter $2.5 \mu \mathrm{m}$. 
Concerning hygrothermal comfort, 37 articles measured the indoor environment in free-running conditions, whereas in 41 articles, a mechanical system was used (16 with a heating system, 9 with a cooling system, and 16 with both systems). Twelve articles did not specify the thermal conditions of the building. Some authors combined both situations of free running and conditioned indoor environment because (1) they studied buildings in different climatic zones [116,118], (2) they compared two indoor environments with different conditions [108], or (3) they measured the same environment over various periods with different conditions [64,73,89], and [99].

In 24 of 100 articles included in this study, the most evaluated IEQ variable was temperature as the sole parameter, mostly in residential buildings. The variable was measured through monitoring, sporadic measurements, and perception surveys.

Temperature measuring aims to quantify the impact of (1) different building envelope solutions [38, 79], roofing [37] or windows [49]; (2) climate variations of adaptive comfort [35,129]; (3) architectural [54] or bioclimatic [81] design; and (4) comfort perception and hygrothermal comfort local regulations $[55,63]$.

Studies analyzing only one IEQ factor were related to lighting [46,58,59,71,83,101,102,112], and ambient noise $[44,77,84,88,93,103,126-128]$, consisting of $8 \%$ for each.

Regarding lighting comfort, illuminance measurements or monitoring in specific environment areas were analyzed, such as workspaces or from a set distance from the window. Few papers took into account the daylight factor, which considers available exterior illuminance. The main topics considered when analyzing this factor were assessment of the potential of innovative [71] or low-cost $[58,59]$ systems; school study cases [46,101]; glare issues [102] or [108]; or effects of lighting designs on comfort levels [83,112].

In terms of acoustic comfort, nine of the ten analyzed articles measured the environment of educational spaces, and one of them measured residential space. These articles registered decibel levels in localized environment spots for a short period. In certain cases, measurements were contrasted with user surveys. The main studied topics were acoustic performance of new building systems [88] or innovative designs [93]; the influence of designs or spaces on schools [103,127]; and noise perception or discomfort in university buildings [77,126,128] or in open office spaces [84]. In [44], the acoustic comfort of a university building was analyzed, highlighting the importance of incorporating acoustic criteria in designs to foster memory, reasoning, interpreting, as well as civic engagement.

There was $38 \%$ of articles that analyzed a combination of comfort types. The most common were hygrothermal and IAQ y or hygrothermal and visual comfort.

The main analysis objectives included effects of air conditioning on the general health [76] and comfort feel [50,51]; analysis of building materials [67,75]; implementation or handling of installed equipment [47,130]; energy consumption and comfort [60]; and social context implications on hygrothermal comfort $[113,119]$.

On the subject of IAQ, studies mainly focused on schools and university buildings. The main assessed indicator was $\mathrm{CO}_{2}$ emissions, although in most cases it was related to other variables. For example, its connection was analyzed with local regulations on air changes [91] or concentration measurements of $\mathrm{PM}, \mathrm{NO}_{2}$, black carbon (BC), and isomer xylenes (BTEX) to determine the effects on asthmatic conditions [74]. On the other hand, only one study [106] measured the concentration of particulate matter PM2.5 and other pollutants in schools. In the case of offices in university buildings, the main assessment referred to the applicability of norm DIN EN 13779 [131] and detecting reasons for a bad response on IAQ [47].

\section{Discussion}

Out of the 100 analyzed articles, 88 focused on hygrothermal comfort according to the variables that have been identified as prominent. Their variables are temperature, relative humidity, lighting, PMV, and air velocity.

In $67.5 \%$ of the case studies, results showed uncomfortable situations for users, where the most analyzed types of comfort were thermal and hygrothermal. As for the former, discomfort was due 
to indoor temperatures well under the accepted ranges for its occupants. However, it is important to mention that the accepted range will depend not only on the geographical location and climate zone but also on the effect of different factors such as outdoor temperature, the occupant's sex and age range, local and individual culture, socio-economic status, and the reality it entails [117]. Type of residence and its usual temperature, lifestyle, clothing layers and their insulation level, and activities and conducts carried out inside the residence (including the metabolic rate of its occupants) must also be considered.

Furthermore, even if regulations can set acceptable temperature ranges, these may not agree with the users' perception. Therefore, in many cases, measurements and survey results may not reach the same conclusions. ASHRAE 55 [132] and ISO 7730 [133] are the most used regulations in case studies. These regulations determine ranges and fixed parameters for their application. It could be troublesome because, as has been mentioned, there will be factors linked to individuals that have greater influence in comfort perception.

Regarding hygrothermal comfort, variations depend on the region in Latin America under consideration, specifically the climate of each location. In warmer and more humid places, a decrease in relative humidity could be perceived as increased heat. For this reason, the combination of temperature and relative humidity is more relevant. On the other hand, in drier and colder climates, relative humidity does not have a significant role, as it does not affect people's perception of temperature. Nonetheless, as individuals would be accustomed to dry environments, an increase in relative humidity could create a heat perception without, and increase in, temperature [78].

As for $\mathrm{CO}_{2}$ concentrations, parts per million (ppm) quantity in the air is usually measured. The results of those measurements showed high concentration levels in closed spaces that did not have enough ventilation. These cases are mostly schools and universities, where the study of this factor is more relevant than cases in which thermal comfort is favored over ventilation. For this reason, air currents are impeded by how the indoor space is used (e.g., windows are not opened or ventilation ducts are closed to avoid temperature fluctuations). Additionally, solar coverage and eaves whose main purpose is to avoid direct solar radiation are mentioned. However, these hinder the airflow or interrupt outdoor currents. In these cases, the combination is not right as the two factors cancel each other.

Furthermore, regarding ventilation, it is worthwhile to consider air velocity and its effects on temperature perception. Speeds lower than $0.25 \mathrm{~m} / \mathrm{s}$ do not affect thermal perception, but above $0.25 \mathrm{~m} / \mathrm{s}$ there will be a cooling feeling that will alter thermal perception without an actual temperature change.

Thus, it is noticeable that none of the three public buildings complied with comfort standards. On the other hand, the 17 studies (57\%) dealing with residential buildings concluded that respondents were not comfortable. This demonstrates a precariousness in the housing sector in Latin America.

Only 5 out of the 20 papers analyzing comfort in schools found that the respondents were comfortable. European studies show a direct link between student academic performance and classroom environment conditions. Good ventilation could impact students' performance up to $14.5 \%$ [134], which is the equivalent of 2 academic years' worth of studying. Likewise, good thermal conditions could improve student performance by up to $3.5 \%$ [134].

Finally, only 25 out of 88 articles ( $28 \%$ ) found that buildings were comfortable. This finding demonstrates a gap existing in Latin America when it comes to providing comfortable indoor environments (Figure 5). 


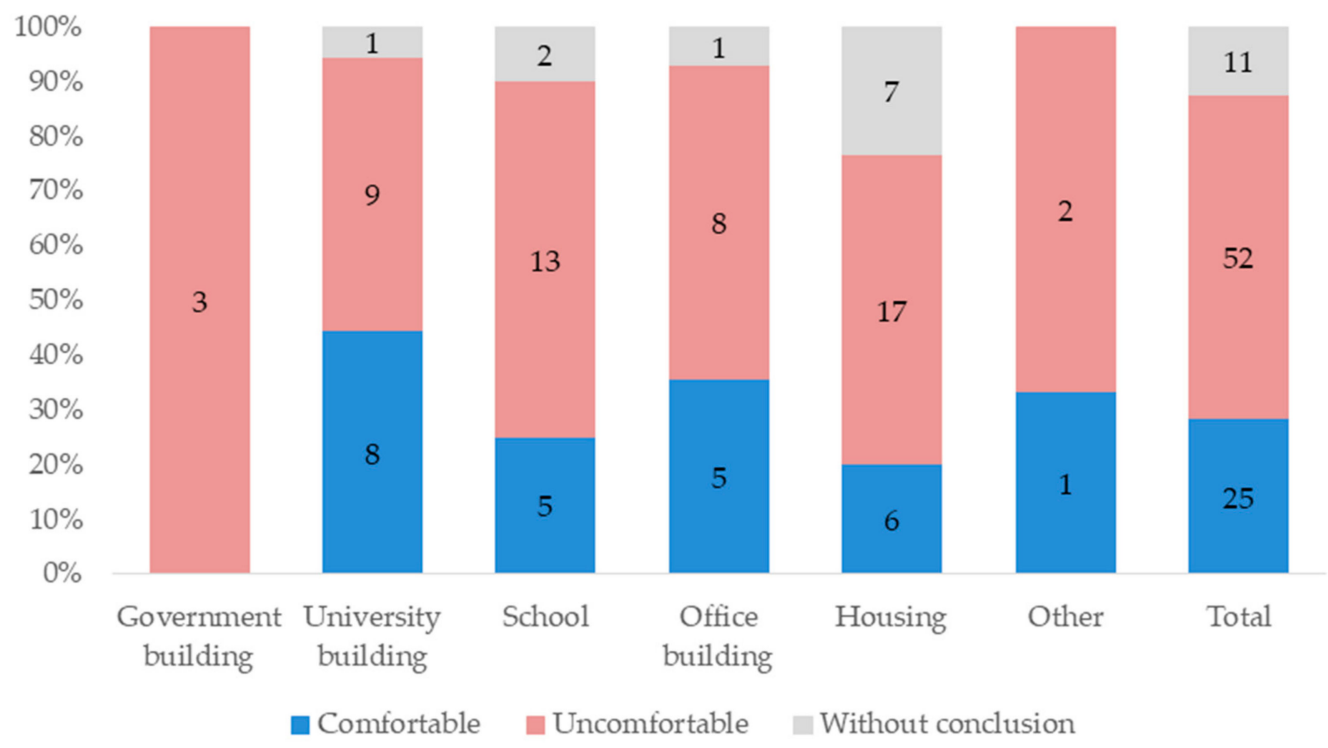

Figure 5. Distribution of building comfort by typology and the total number of studies considered. Source: By Authors.

\section{Conclusions}

The current systematic literature review on indoor environment quality in existing buildings in Latin America demonstrated that Brazil and Argentina led these types of studies in schools and housing buildings. It was also noted that hygrothermal comfort was the most analyzed comfort type, with temperature and humidity leading the number of studies. Most studies evaluated comfort along with one or more variables, as well as more than one type of comfort. Regarding evaluation strategies, it was noted that most studies used a combination of one or two strategies. The main implemented strategies were specific and constant measurements and surveys.

The result of the analysis shows a lack of studies concerned with building users sensitive to indoor environment quality (e.g., nurseries, senior residences, or health buildings). There was also a discrepancy between objective measuring methods and user perception. Additionally, the result showed the importance of continuing the analysis of less-studied variables such as ambient noise, lighting, and air quality $\left(\mathrm{CO}_{2}, \mathrm{CO}, \mathrm{PM}\right)$.

Detailed analysis of predominant variables of indoor environment quality showed that local factors such as socioeconomic status, education level, and the precariousness of building solutions in residences and schools affected IEQ in Latin American buildings. Furthermore, most Latin American buildings are not completely comfortable; thus, it is necessary to improve architectural designs, regulatory standards, educate users, or improve building monitoring management at the operational stage.

Author Contributions: Conceptualization, C.V.-U., methodology C.R.-C.; formal analysis, C.V.-U., C.S.-G., and L.S.-C.; investigation, C.V.-U., C.R.-C., and L.S.-C.; data curation, C.S.-G. and F.R.; writing-original draft preparation, C.V.-U., C.R.-C., and L.S.-C.; writing-review and editing, C.V.-U., C.S.-G., and F.R.; visualization, C.V.-U.; supervision, C.V.-U. All authors have read and agreed to the published version of the manuscript.

Funding: This research received no external funding.

Conflicts of Interest: The authors declare no conflict of interest.

\section{References}

1. Environmental Protection Agency. Healthy Buildings, Healthy People: A Vision for the 21st Century; Office of Air and Radiation, US EPA: Washington, DC, USA, 2014; p. 29.

2. Jansz, J. Introduction to Sick Building Syndrome (SBS). In Sick Building Syndrome; Springer: Berlin/Heidelberg, Germany, 2011; pp. 1-24. 
3. Nordstrom, K.; Norback, D.; Akselsson, R. Influence of indoor air quality and personal factors on the sick building syndrome (SBS) in Swedish geriatric hospitals. Occup. Environ. Med. 1995, 52, 170-176. [CrossRef] [PubMed]

4. Rodríguez-Hernández, L.; Alonzo-Salomón, J. Efectos de los factores ambientales, laborales y psicosociales en el síndrome del edificio enfermo. Ingeniería 2004, 8, 1-8.

5. World Health Organization. Contaminación del Aire de Interiores y Salud. Available online: https: //www.who.int/es/news-room/fact-sheets/detail/household-air-pollution-and-health (accessed on 20 March 2019).

6. Meerding, W.J.; Ijzelenberg, W.; Koopmanschap, M.A.; Severens, J.L.; Burdorf, A. Health problems lead to considerable productivity loss at work among workers with high physical load jobs. J. Clin. Epidemiol. 2005, 58, 517-523. [CrossRef] [PubMed]

7. Collins, J.J.; Baase, C.; Sharda, C.; Ozminkowski, R.; Nicholson, S.; Billotti, G.; Turpin, R.; Olson, M.; Berger, M. The assessment of chronic health conditions on work performance, absence, and total economic impact for employers. J. Occup. Environ. Med. 2005, 47, 547-557. [CrossRef]

8. Seppanen, O.; Fisk, W.J.; Lei, Q.H. Effect of Temperature on Task Performance in Office Environment; Ernest Orlando Lawrence Berkeley National Laboratory: Berkeley, CA, USA, 2006.

9. Olesen, B.W. The philosophy behind EN15251: Indoor environmental criteria for design and calculation of energy performance of buildings. Energy Build. 2007, 39, 740-749. [CrossRef]

10. Ncube, M.; Riffat, S. Developing an indoor environment quality tool for assessment of mechanically ventilated office buildings in the UK-A preliminary study. Build. Environ. 2012, 53, 26-33. [CrossRef]

11. Muhič, S.; Butala, V. The influence of indoor environment in office buildings on their occupants: Expected-unexpected. Build. Environ. 2004, 39, 289-296. [CrossRef]

12. Rupp, R.F.; Vásquez, N.G.; Lamberts, R. A review of human thermal comfort in the built environment. Energy Build. 2015, 105, 178-205. [CrossRef]

13. Djongyang, N.; Tchinda, R.; Njomo, D. Thermal comfort: A review paper. Renew. Sustain. Energy Rev. 2010, 14, 2626-2640. [CrossRef]

14. Taleghani, M.; Tenpierik, M.; Kurvers, S.; van den Dobbelsteen, A. A review into thermal comfort in buildings. Renew. Sustain. Energy Rev. 2013, 26, 201-215. [CrossRef]

15. Sundell, J.; Levin, H.; Nazaroff, W.W.; Cain, W.S.; Fisk, W.J.; Grimsrud, D.T.; Gyntelberg, F.; Li, Y.; Persily, A.K.; Pickering, A.C.; et al. Ventilation rates and health: Multidisciplinary review of the scientific literature. Indoor Air 2011, 21, 191-204. [CrossRef] [PubMed]

16. Ortiz, M.A.; Kurvers, S.R.; Bluyssen, P.M. A review of comfort, health, and energy use: Understanding daily energy use and wellbeing for the development of a new approach to study comfort. Energy Build. 2017, 152, 323-335. [CrossRef]

17. Vásquez-Hernández, A.; Restrepo Álvarez, M.F. Evaluation of buildings in real conditions of use: Current situation. J. Build. Eng. 2017, 12, 26-36. [CrossRef]

18. Boshell, F.; Veloza, O.P. Review of developed demand side management programs including different concepts and their results. In Proceedings of the 2008 IEEE/PES Transmission and Distribution Conference and Exposition: Latin America, Bogota, Colombia, 13-15 August 2008.

19. Chatzidiakou, L.; Mumovic, D.; Summerfield, A.J. What do we know about indoor air quality in school classrooms? A critical review of the literature. Intell. Build. Int. 2012, 4, 228-259. [CrossRef]

20. Zomorodian, Z.S.; Tahsildoost, M.; Hafezi, M. Thermal comfort in educational buildings: A review article. Renew. Sustain. Energy Rev. 2016, 59, 895-906. [CrossRef]

21. Daisey, J.M.; Angell, W.J.; Apte, M.G. Indoor air quality, ventilation and health symptoms in schools: An analysis of existing information. Indoor Air 2003, 13, 53-64. [CrossRef]

22. Dascalaki, E.G.; Sermpetzoglou, V.G. Energy performance and indoor environmental quality in Hellenic schools. Energy Build. 2011, 43, 718-727. [CrossRef]

23. Martínez-Molina, A.; Tort-Ausina, I.; Cho, S.; Vivancos, J.L. Energy efficiency and thermal comfort in historic buildings: A review. Renew. Sustain. Energy Rev. 2016, 61, 70-85. [CrossRef]

24. Antoniadou, P.; Papadopoulos, A.M. Occupants' thermal comfort: State of the art and the prospects of personalized assessment in office buildings. Energy Build. 2017, 153, 136-149. [CrossRef]

25. Ortony, A. Who Needs Emotions; Oxford University Press: New York, NY, USA, 2005. 
26. Fassio, F.; Fanchiotti, A.; Vollaro, R. Linear, non-linear and alternative algorithms in the correlation of IEQ factors with global comfort: A case study. Sustainability 2014, 6, 8113-8127. [CrossRef]

27. D'Alencon, R. Acondicionamientos: Arquitectura y técnica; ARQ Edificio: Santiago, Chile, 2008; p. 220.

28. Moher, D.; Liberati, A.; Tetzlaff, J.; Altman, D.; PRISMA Group. Preferred reporting items for systematic reviews and meta-analyses: The PRISMA Statement. Ann. Intern. Med. 2009, 151, 264-269. [CrossRef] [PubMed]

29. Adiane Borges, D.; Rosa Paiva, E.C.; Panazzolo Sarmento, A.; Alves de Resende, A. Análise de condições térmicas nos blocos didáticos da Universidade Federal de Goiás-Regional Catalão. REEC Rev. Eletron. Eng. Civ. 2016, 11. [CrossRef]

30. Akutsu, M.; Camargo de Brito, A.; de Mello Aquilino, M.; dos Reis Filho, A.; Santos da Silva, W. O efeito da inércia térmica de paredes no desempenho térmico de edificações escolares. In Proceedings of the XII Encontro Nacional e VIII Encontro Latino-Americano de Conforto no Ambiente Construído (ENCAC-ELACAC), Brasilia, Brazil, 25-27 September 2013.

31. Alías, H.M.; Jacobo, G.J.; Gallipoliti, V.A.; Martina, P.E.; Corace, J.J.; Aeberhard, M.R.; di Bernardo, A. Relevamiento del parque habitacional social de resistencia y corrientes y su desempeño térmico: Monitoreo y simulaciones. Av. Energías Renov. Medio Ambient. 2010, 14, 89-96.

32. Alonso Frank, A.; Kuchen, E.; Toranzo, E. Diagnóstico de la calidad del aire en espacios de trabajo en el edificio Central de la Universidad Nacional de San Juan, Argentina. Av. Energías Renov. Medio Ambient. 2012, 16, 65-72.

33. Alonso Frank, A.; Kuchen, E.; Arballo, B.; Alamino Naranjo, Y. Influencia de la calidad ambiental edilicia y térmica del usuario en la eficiencia energética de edificios públicos. Casos de estudio: Edificio de Obras Sanitarias Sociedad del Estado, San Juan, Argentina. Av. Energías Renov. Medio Ambient. 2015, 19, $13-22$.

34. Alves, C.A.; Ghosn, A.; Lorenzetti, N.; Pinha, A.; Proença, M.; Silva, P. Study of the thermal performance of the entrance hall of 'Vila Penteado' building. In Proceedings of the Euro Elecs 2017, Sao Leopoldo, Brazil, 10-13 May 2017; pp. 259-269.

35. Alves, C.A.; Duarte, D.H.; Gonçalves, F.L. Residential buildings' thermal performance and comfort for the elderly under climate changes context in the city of São Paulo, Brazil. Energy Build. 2016, 114, 62-71. [CrossRef]

36. Armijo, G.; Whitman, C.; Casals, R. Post-occupancy evaluation of state schools in 5 climatic zones of Chile. Gazi Univ. J. Sci. 2011, 24, 365-374.

37. Barbosa Teixeira, C.; Chebel Labaki, L. The springer thermal behaviour of roofing coatings on dry period: Application in a house in Campinas, Brazil. In Proceedings of the 28th International PLEA Conference on Sustainable Architecture (PLEA 2012), Lima, Peru, 7-9 November 2012.

38. Becerra-Santacruz, H.; Lawrence, R. Evaluation of the thermal performance of an industrialised housing construction system in a warm-temperate climate: Morelia, Mexico. Build. Environ. 2016, 107, 135-153. [CrossRef]

39. Betancourt-Velasco, M.; García-Alvarado, R. Design guidelines for residential envelope openings in the equatorial tropics: Studies in suburban housing in the Cauca valley of Colombia. In Proceedings of the 28th International PLEA Conference on Sustainable Architecture (PLEA 2012), Lima, Peru, 7-9 November 2012.

40. Biondi, D.; Martini, A.; de Lima-Neto, E.M. Uma introdução ao conforto termo-ambiental do colégio Estadual Santa Gemma Galgani, Curitiba, Paraná, Brasil. FLORESTA 2014, 45, 409-420. [CrossRef]

41. Boutet, M.L.; Hernández, A.L.; Jacobo, G.J.; Martina, P.E.; Corace, J.J. Auditorías higrotérmicas y lumínicas de dos edificios escolares de nivel inicial de la ciudad de resistencia, en condiciones reales de ocupación. Av. Energías Renov. Medio Ambient. 2011, 15, 29-36.

42. Boutet, M.L.; Hernández, A.L.; Jacobo, G.J. Propuesta de optimización del comportamiento higrotérmico-Lumínico, de un edificio escolar de la región N.E.A. a partir de monitoreo y simulación en período de otoño. Av. Energías Renov. Medio Ambient. 2013, 17, 1-10.

43. Bravo, G.; González, E. Thermal comfort in naturally ventilated spaces and under indirect evaporative passive cooling conditions in hot-humid climate. Energy Build. 2013, 63, 79-86. [CrossRef]

44. Bressane, A.; Alves de Castro, M.; Satie Mochizuki, P. Poluição sonora em edificações: Avaliação do conforto acústico e de sua percepção na Biblioteca Universitária Da UNESP, Campus De Rio Claro (SP). OLAM Cienc. Tecnol. 2009, 9, 231. 
45. Bustamante, W.; Encinas, F.; Vasquez, C.; Vera, S. Architectural design strategies based on experimental analysis in office buildings in Santiago, Chile. In Proceedings of the 28th International PLEA Conference on Sustainable Architecture (PLEA 2012), Lima, Peru, 7-9 November 2012.

46. Cisterna, M.S.; Ledesma, S.L.; Llabra, C.; Marquez-Vega, S.G.; Martínez, C.F.; Nota, V.M.; Quiñones, G.I.; Mostajo, M.; Gonzalo, G.E. Condiciones de habitabilidad y confort en edificios escolares. Iluminación natural en aulas de escuelas de Tafi del Valle, Tucumán. Av. Energías Renov. Medio Ambient. 2015, 3, $25-37$.

47. Corallo, F.; Kuchen, E.; Gonzalo, G.E. Evaluación de los conceptos energéticos y del confort térmico en el edificio Central de la Universidad Nacional de San Juan. In Proceedings of the XIV Encontro Nacional de Tecnologia do Ambiente Construído, (ENTAC), Juiz de Fora, Brazil, 29-31 October 2012; pp. 3209-3219.

48. Corvalán, R.E.; Ferrari, E.; Sanabria, N.A.; Titiosky, V.; Sáenz Pérez, J.; Amarilla, A.; Peris, J.; Marsilli, C.; Larrea, D. Iluminación y confort en aulas y laboratorios de carreras técnicas de grado universitario. Ext. Innov. Transf. Tecnol. 2015, 2, 98-105. [CrossRef]

49. Dalbem, R.; Duarte, C.M.; Medvedovski, N.S.; Cunha, E.G. Influência do usuário no conforto térmico de um edifício devido à operação de janelas. Rev. Arquitetura IMED 2016, 5, 104-119. [CrossRef]

50. De Vecchi, R.; Cândido, C.; de Dear, R.; Lamberts, R. Thermal comfort in office buildings: Findings from a field study in mixed-mode and fully-air conditioning environments under humid subtropical conditions. Build. Environ. 2017, 123, 672-683. [CrossRef]

51. De Vecchi, R.; Cândido, C.; Lamberts, R. Thermal history and comfort in a Brazilian subtropical climate: A 'cool' addiction hypothesis. Ambient. Construído 2016, 16, 7-20. [CrossRef]

52. Delbene, C.; Evans, J.M. Metodología de análisis para evaluar mejoras en el confort interior modificando la envolvente en un edificio de perimetro libre. Av. Energías Renov. Medio Ambient. 2010, 14, 165-172.

53. Esparza-López, C.J.; Alcántara-Lomelí, A.; Gómez-Amador, A.; Gónzalez-Trevizo, M.E. Analysis thermo-hygric of occupied social welfare housing in a warm sub-humid weather. In Proceedings of the 28th International PLEA Conference on Sustainable Architecture (PLEA 2012), Lima, Peru, 7-9 November 2012.

54. Esparza-López, C.J.; Alcántara-Lomelí, A.; Gómez-Amador, A.; Gónzalez-Trevizo, M.E. Human adaptive ability in social welfare housing in response to environmental conditions of a space. In Proceedings of the 28th International PLEA Conference on Sustainable Architecture (PLEA 2012), Lima, Peru, 7-9 November 2012.

55. Espinosa Cancino, C.F.; Cortés Fuentes, A. Confort higro-térmico en vivienda social y la percepción del habitante. Rev. INVI 2015, 30, 227-242. [CrossRef]

56. Fastofski, D.C.; González, M.A.; Kern, A.P. Sustainability analysis of housing developments through the Brazilian environmental rating system Selo Casa Azul. Habitat Int. 2017, 67, 44-53. [CrossRef]

57. Felippe, M.L.; Kuhnen, A.; Silveira, B.B. Como seria uma escola ideal? o que dizem os estudantes. Rev. Psicol. IMED 2016, 8, 109-121. [CrossRef]

58. Ferrón, L.; Pattini, A.; Lara, M.A. Aplicabilidad de sistemas de iluminación natural de bajo costo. refuncionalización Lumínica en una oficina. Energías Renov. Medio Ambient. 2010, 25, 57-63.

59. Ferrón, L.; Pattini, A.; Lara, M.A. Use of low-cost daylighting system: Custom design and application consequences in an office environment. Int. J. Low Carbon Technol. 2011, 6, 149-155. [CrossRef]

60. Filippín, C.; Flores-Larsen, S.; Marek, L. Experimental monitoring and post-occupancy evaluation of a non-domestic solar building in the central region of Argentina. Energy Build. 2015, 92, 267-281. [CrossRef]

61. Filippín, C.; Flores-Larsen, S. Summer thermal behaviour of compact single family housing in a temperate climate in Argentina. Renew. Sustain. Energy Rev. 2012, 16, 3439-3455. [CrossRef]

62. Filippín, C.; Flores-Larsen, S.; Mercado, V. Winter energy behaviour in multi-family block buildings in a temperate-cold climate in Argentina. Renew. Sustain. Energy Rev. 2011, 15, 203-219. [CrossRef]

63. Filippín, C.; Sipowicz, E.; Flores-Larsen, S. Monitoreo energético experimental de vivienda unifamiliar compacta en un clima templado frío de Argentina. Ambient. Construído 2013, 13, 249-267. [CrossRef]

64. Follari, J.; Filippín, C. Proyecto demostrativo bioclimatico en San Luis. Tecnologia y monitoreo termico experimental. Energías Renov. Medio Ambient. 2011, 27, 31-43.

65. Forero Cortés, C.; Devia Castillo, C.A. Mejora de las condiciones de habitabilidad y del cambio climático a partir de ecotechos extensivos. Estudio de caso: Barrio La Isla, Altos de Cazucá, Soacha, Cundinamarca. Cuad. Vivienda Urban. 2011, 4, 316-329. 
66. Forgiarini-Rupp, R.; De Vecchi, R.; Asmus, B.; Candido, C.; Ghisi, E. Aplicabilidade do modelo PMV/PPD para avaliação de conforto térmico em escritórios com sistema central de condicionamento artificial em Florianópolis/Sc. In Proceedings of the XIII Encontro Nacional e IX Encontro Latino-americano de Conforto no Ambiente Construído (ENCAC, ELACAC), Sao Paolo, Brazil, 14-18 October 2015.

67. Fortes Goulart, M.; Almeida Dornelles, K.; Caram, R. Avaliação do desempenho térmico da envoltória do Colégio de Aplicação Pedagógica da Universidade Estadual de Maringá. In Proceedings of the XII Encontro Nacional e VIII Encontro Latino-Americano de Conforto no Ambiente Construído (ENCAC, ELACAC), Brasilia, Brazil, 25-27 September 2013.

68. Gallegos-Ortega, R.; Magaña-Guzmán, T.; Reyes-López, J.A.; Romero-Hernández, M.S. Thermal behavior of a straw bale building from data obtained in situ. A case in Northwestern México. Build. Environ. 2017, 124, 336-341. [CrossRef]

69. Gallipoliti, V.; Jacobo, G.; Martina, P.; Corace, J. Analisis constructivo y de desempeño higrotermico-Energético en aulas del edificio de la facultad de arquitectura de la UNE para periodo de invierno. Av. Energías Renov. Medio Ambient. 2012, 16, 57-64.

70. García Alvarado, R.; Herrera Ojeda, R.; Muñoz Viveros, C.; Wandersleben, G. Desempeño ambiental de recintos habitacionales. Comparación de simulaciones, monitorización y percepción de residentes en seis viviendas de Concepción, Chile. Rev. Tecnura 2016, 20, 71-84. [CrossRef]

71. García-Chávez, J.R.; Díaz-Báez, A. The potential of an innovative sunlight system to improve luminous comfort in buildings application of a specular sunlight device in real buildings. In Proceedings of the 28th International PLEA Conference on Sustainable Architecture (PLEA 2012), Lima, Peru, 7-9 November 2012.

72. García-López, E.; Heard, C. A study of the social acceptability of a proposal to improve the thermal comfort of a traditional dwelling. Appl. Therm. Eng. 2015, 75, 1287-1295. [CrossRef]

73. Garganta, L.; Murace, P.; Gomez, E. Auditoría energética y ambiental de una vivienda unifamiliar 'Tipo Cajón' ubicada en la ciudad de La Plata, Buenos Aires. In Proceedings of the I Encuentro Nacional Sobre Ciudad, Arquitectura y Construcción Sustentable, La Plata, Argentina, 23-27 May 2016; pp. 291-302.

74. Godoi, R.H.M.; Avigo, D., Jr.; Campos, V.P.; Tavares, T.M.; de Marchi, M.R.R.; Van Grieken, R.; Godoi, A.F.L. Indoor air quality assessment of elementary schools in Curitiba, Brazil. Water Air Soil Pollut. Focus 2009, 9, 171-177. [CrossRef]

75. Gómez-Amador, A.; García, A.; Ochoa, J.M.; Herrera, L. Natural ventilation in a traditional lattice in Colima, México. In Proceedings of the 28th International PLEA Conference on Sustainable Architecture (PLEA 2012), Lima, Peru, 7-9 November 2012.

76. Gomez-Azpeitia, G.; Martínez-Torres, K.E. Thermal comfort and health conditions in air-conditioned offices in a warm and sub-humid climate. In Proceedings of the 28th International PLEA Conference on Sustainable Architecture (PLEA 2012), Lima, Peru, 7-9 November 2012.

77. Henrique dos Santos, P.; de Souza Junior, D.A.; dos Santos, C. Análise do conforto acústico de salas de aula do Campus Santa Mônica-UFU: Estudo de caso. Acta Científica 2015, 7, 13-23. [CrossRef]

78. Herrera, L.C.; Gómez-Azpeitia, G. Neutral humidity in low cost dwellings in arid climate. In Proceedings of the 28th International PLEA Conference on Sustainable Architecture (PLEA 2012), Lima, Peru, 7-9 November 2012.

79. Krüger, E.L.; Laroca, C. Thermal performance evaluation of a low-cost housing prototype made with plywood panels in Southern Brazil. Appl. Energy 2010, 87, 661-672. [CrossRef]

80. Leite-Frandoloso, M.A.; Londero-Brandli, L.; Pedroso Dias, F. How to improve eco-efficiency and indoor comfort at University of Passo Fundo, Brazil. In Proceedings of the 28th International PLEA Conference on Sustainable Architecture (PLEA 2012), Lima, Peru, 7-9 November 2012.

81. Lelis-Rabelo, P.; Pujadas-Tafra, S.; Durán-Palma, J. Analysis of environmental performance in a social housing: Housing complex at Conchalí, Santiago of Chile. In Proceedings of the 28th International PLEA Conference on Sustainable Architecture (PLEA 2012), Lima, Peru, 7-9 November 2012.

82. Lukiantchuki, M.A.; Caram, R.M. Análise do conforto térmico na obra de João Filgueiras Lima, Lelé: Hospitais Sarah de Salvador e do Rio de Janeiro. In Proceedings of the XII Encontro Nacional e VIII Encontro Latino-Americano de Conforto no Ambiente Construído (ENCAC, ELACAC), Brasilia, Brazil, 25-27 September 2013. 
83. Manzano, E.; Assaf, L.; Raitelli, M.; Cabello, A.; Deco, F.; Tapia-garzón, J.; Brito, R.; Carlorosi, M. Avances sobre eficiencia y sostenibilidad en la iluminación de recintos urbanos y edificios. Energías Renov. Medio Ambient. 2012, 29, 7-12.

84. Marcon-Passero, C.; Trombetta-Zannin, P. O conforto acústico em escritórios panorâmicos: Estudo de caso em um escritório real. Ambient. Construìdo 2009, 9, 93-105.

85. Marincic, I.; Ochoa, J.M.; Del Río, J.A. Mathematical model for thermal votes: Two seasons comparison. In Proceedings of the 28th International PLEA Conference on Sustainable Architecture (PLEA 2012), Lima, Peru, 7-9 November 2012.

86. Martines-Torres, K.; Gomez-Azpeitia, G.; Bojorquez-Morales, G. Adaptive thermal comfort for air-conditioned offices in a warm sub-humid climate. In Proceedings of the 28th International PLEA Conference on Sustainable Architecture (PLEA 2012), Lima, Peru, 7-9 November 2012.

87. Matheus, C.; Labaki, L.C.; Castro, A.P.; Matsumoto, E. Thermal comfort in a semi-open area: A residence built as a veranda with green roof. In Proceedings of the 28th International PLEA Conference on Sustainable Architecture (PLEA 2012), Lima, Peru, 7-9 November 2012.

88. Matoski, A.; Scoczynski-Ribeiro, R.S. Evaluation of the acoustic performance of a modular construction system: Case study. Appl. Acoust. 2016, 106, 105-112. [CrossRef]

89. Mercado, V.; Esteves, A.; Filippín, C. Comportamiento térmico-energético de una vivienda social de la ciudad de Mendoza, Argentina. Ambient. Construído 2010, 10, 87-100. [CrossRef]

90. Molina, C.; Veas, L. Evaluación del confort térmico en recintos de 10 edificios públicos de Chile en invierno. Rev. Constr. 2012, 11, 27-38. [CrossRef]

91. Molina, C.; Veas, L.; Ossio, F. Case study: Environmental quality in classrooms of South of Chile. Carbon dioxide concentration levels and satisfaction polls. In Proceedings of the 28th International PLEA Conference on Sustainable Architecture (PLEA 2012), Lima, Peru, 7-9 November 2012.

92. Morales-Soler, E.; Mallen, R.A.; Moreno-Cruz, E. La vivienda como proceso. Estrategias de flexibilidad. Habitat Soc. 2012, 4, 33-54. [CrossRef]

93. Mundo-Hernández, J.; Sosa-Oliver, J.; Valerdi-Nochebuena, M.C. La percepción de los usuarios del centro cultural La Monja respecto a su acústica y confort ambiental. In Proceedings of the IV Congreso Iberoamericano de Acústica, Coimbra, Portugal, 20-22 October 2008.

94. Mundo-Hernández, J.; Valerdi-Nochebuena, M.C.; Sosa-Oliver, J. Post-occupancy evaluation of a restored industrial building: A contemporary art and design gallery in Mexico. Front. Archit. Res. 2015, 4, 330-340. [CrossRef]

95. Muñoz Vásquez, N.; Marino, B.M.; Thomas, L.P. Caracterización térmica de un edificio del centro Bonaerense mediante mediciones y modelado analítico. Av. Energías Renov. Medio Ambient. 2014, 18, 19-28.

96. Ninaquispe-Romero, L.; Weeks, S.; Huelman, P. Totora: A sustainable insulation material for the Andean parts of Peru. In Proceedings of the 28th International PLEA Conference on Sustainable Architecture (PLEA 2012), Lima, Peru, 7-9 November 2012.

97. do Couto Nince, P.C.; De Musis, C.R.; Biudes, M.S.; de Souza Nogueira, J.; Albuquerque Nogueira, M.C. Usos dos índices PET e UTCI na avaliação do conforto termal no Campus da UFMT em Cuiabá-MT. Rev. Eletrônica Gestão Educ. Tecnol. Ambient. 2013, 9, 2026-2036. [CrossRef]

98. Orce-Schwarz, S.; Flores-Larsen, S.; Filippín, C. Energy thermal redesign of a bioclimatic school through monitoring and simulation. In Proceedings of the 28th International PLEA Conference on Sustainable Architecture (PLEA 2012), Lima, Peru, 7-9 November 2012.

99. Oropeza-Perez, I.; Petzold-Rodriguez, A.H.; Bonilla-Lopez, C. Adaptive thermal comfort in the main Mexican climate conditions with and without passive cooling. Energy Build. 2017, 145, 251-258. [CrossRef]

100. Padilha Montanheiro, F.; Gomes de Faria, J.R. Thermal perception of Brazilian elderly in an air-conditioned room: A first approach. PARC Pesqui. Arquitetura Construção 2016, 7, 202-210. [CrossRef]

101. Palme, M.; Saldías-Moreno, K.; Segovia-Ramos, C. Monitorización, simulación y reacondicionamiento lumínico de una sala de clase en Antofagasta. In Proceedings of the XII Encontro Nacional e VIII Encontro Latino-Americano de Conforto no Ambiente Construído (ENCAC, ELACAC), Brasilia, Brazil, 25-27 September 2013.

102. Pattini, A.; Rodríguez, R.; Lassagno, C.; Villalba, A.; Córica, L.; Ferrón, L.; del Rosso, R. Evaluación de deslumbramiento en edificios con iluminación natural en climas soleados. El caso de una biblioteca con techo vidriado. Av. Energías Renov. Medio Ambient. 2009, 13, 169-177. 
103. Santos Pereira, C.A.; Souza Silva, L.C.; Silva Sales, F.H. Análise do nível de conforto acústico na biblioteca de uma escola pública. HOLOS 2011, 4, 65-90. [CrossRef]

104. Piccion, A.; Milicua, S.; Lopez, M.N.; Camacho, M. Adaptive thermal comfort studies in public buildings, Uruguay case of moderate climate. In Proceedings of the 28th International PLEA Conference on Sustainable Architecture (PLEA 2012), Lima, Peru, 7-9 November 2012.

105. Picción, A.; Camacho, M.; Cheirasco, G.; Noel López, M.; Milicua, S. Estudio de campo sobre las condiciones de confort térmico y visual en edificios de enseñanza públicos en clima templado. Av. Energías Renov. Medio Ambient. 2010, 14, 151-157.

106. Raysoni, A.U.; Stock, T.H.; Sarnat, J.A.; Montoya Sosa, T.; Sarnat, S.E.; Holguin, F.; Greenwald, R.; Johnson, B.; Li, W.W. Characterization of traffic-related air pollutant metrics at four schools in El Paso, Texas, USA: Implications for exposure assessment and siting schools in urban areas. Atmos. Environ. 2013, 80, 140-151. [CrossRef]

107. Re, G.; Blasco Lucas, I. Análisis del comportamiento higrotérmico y energético de departamentos en edificios residenciales de la ciudad de La Plata. Av. Energías Renov. Medio Ambient. 2014, 813, 1-8.

108. Re, G.; Blasco Lucas, I. Hygrothermal, lighting and energy behaviors analysis of two apartments in residential buildings located in the city of la Plata, Argentina. In Proceedings of the 28th International PLEA Conference on Sustainable Architecture (PLEA 2012), Lima, Peru, 7-9 November 2012.

109. Re, G.; Blasco Lucas, I.; Filippín, C. Evaluación del Comportamiento térmico de una escuela típica en la ciudad de San Juan, Argentina. Av. Energías Renov. Medio Ambient. 2015, 3, 35-46.

110. Re, G.; Blasco Lucas, I.; Filippín, C. Comportamiento higrotérmico y energético en período estival de un edificio escolar típico en la ciudad de San Juan, Argentina. In Proceedings of the I Encuentro Nacional Sobre Ciudad, Arquitectura y Construcción Sustentable (ENCACS 2016), La Plata, Argentina, 23-27 May 2016.

111. Re, G.; Blasco Lucas, I.; Filippín, C. Evaluación higrotérmica y energética de un edificio escolar perteneciente al programa nacional 700 escuelas, en el área Metropolitana de San Juan, Argentina. Rev. Hábitat SustenTable 2014, 6, 40-51.

112. Rodríguez, R.; Pattini, A. Determinación de satisfacción visual por medio de evaluaciones post ocupacionales en edificios no residenciales. El caso de oficinas. Av. Energías Renov. Medio Ambient. 2010, 14, 57-64.

113. Soto-Muñoz, J.; Trebilcock, M.; Pérez-Fargallo, A. Sustainable educational buildings: A proposal for changes to investment evaluation policies in Chile through the incorporation of thermal comfort and air quality criteria. In Proceedings of the 14th International Conference on Sustainable Energy Technologies, (SET2015), Nottingham, UK, 25-27 August 2015.

114. Toranzo, E.; Kuchen, E.; Alonso, A. Potenciales de eficiencia y confort para un mejor funcionamiento del Edificio Central de la Universidad Nacional de San Juan. Av. Energías Renov. Medio Ambient. 2012, 16, 157-164.

115. Trebilcock, M.; Bobadilla, A.; Piderit-Moreno, B.; Guzmán, F.; Figueroa-San Martín, R.; Soto, C.; Hernández, J. Environmental performance of schools in areas of cultural sensitivity. In Proceedings of the 28th International PLEA Conference on Sustainable Architecture (PLEA 2012), Lima, Peru, 7-9 November 2012.

116. Trebilcock, M.; Piderit-Moreno, B.; Soto-Muñoz, J.; Figueroa-San Martín, R. A parametric analysis of simple passive strategies for improving thermal performance of school classrooms in Chile. Archit. Sci. Rev. 2016, 59, 385-399. [CrossRef]

117. Trebilcock, M.; Soto-Muñoz, J.; Yañez, M.; Figueroa-San Martin, R. The right to comfort: A field study on adaptive thermal comfort in free-running primary schools in Chile. Build. Environ. 2017, 114, 455-469. [CrossRef]

118. Trebilcock, M.; Soto-Muñoz, J.; Figueroa-San Martin, R.; Piderit-Moreno, B. Metodología para el diseño de edificios educacionales confortables y resilientes. Rev. AUS 2015, 20, 70-76. [CrossRef]

119. Trebilcock, M.; Soto-Muñoz, J.; Figueroa-San Martín, R. Thermal comfort in primary schools: A field study in Chile. In Proceedings of the 8th Windsor Conference: Counting the Cost of Comfort in a Changing World, Windsor, UK, 10-13 April 2014.

120. Vargas, E.; Saelzer, G. Parametric Study of Thermal Comfort and Energy Performance of Naturally Ventilated Classrooms in the Tropic of Costa Rica. In Proceedings of the 32nd International PLEA Conference on Sustainable Architecture (PLEA 2016), Los Angeles, CA, USA, 11-13 July 2016. 
121. Vásquez, C.; Prieto, A.; Aguirre, C. Characterization of summer thermal behaviour of 'Class A' office buildings in Santiago, Chile. In Proceedings of the 28th International PLEA Conference on Sustainable Architecture (PLEA 2012), Lima, Peru, 7-9 November 2012.

122. Vásquez, C.; Encinas, F.; Prieto, A.; Aguirre, C. Thermal and lighting perception in four fully glazed office buildings in Santiago, Chile. J. Facade Des. Eng. 2013, 1, 31-51. [CrossRef]

123. Viloria, A.; Acuna, N.; Mejia, H.; Galofre, M. Determination of the influence of thermal comfort in care and concentration of media education students: Case Colombia. Indian J. Sci. Technol. 2016, 9(46), 1-5. [CrossRef]

124. Wegertseder, P.; Trebilcock, M. Post occupancy evaluation for energy and environmental retrofitting of existing social housing in Chile: Development of performance-based strategies. In Proceedings of the 28th International PLEA Conference on Sustainable Architecture (PLEA 2012), Lima, Peru, 7-9 November 2012.

125. Wrobel-Straub, K.; Toledo Borges Leão, E.F.; Kuchen, E.; Leão, M. Determinação da temperatura de neutralidade em salas de aula do ensino superior para as zonas bioclimáticas do estado de Mato Grosso. Ambient. Construído 2017, 17, 97-109. [CrossRef]

126. Zannin, P.H.T.; Engel, M.S.; Fiedler, P.E.K.; Bunn, F. Characterization of environmental noise based on noise measurements, noise mapping and interviews: A case study at a university campus in Brazil. Cities 2013, 31, 317-327. [CrossRef]

127. Zannin, P.H.T.; Zwirtes, D.P.Z. Evaluation of the acoustic performance of classrooms in public schools. Appl. Acoust. 2009, 70, 626-635. [CrossRef]

128. Zapata González, L.; Quiceno Hoyos, A.; Zeng Huang, O. Evaluación de la comodidad auditiva en ambientes pedagógicos de la Universidad Católica de Manizales, Colombia. Arquetipo 2015, 11, 41-60.

129. Marincic, I.; Ochoa, J.M.; Alpuche, M.G.; González, I. Comparative analysis of the thermal behavior between cellular concrete blocks and stabilized earth blocks as wall materials. Energy Procedia 2014, 57, 1783-1791. [CrossRef]

130. Morales Adames, G.A.; García Álvarez, M.C. Problemas de confort térmico en edificios de oficinas. Caso estudio: Torre Colpatria en la Ciudad de Bogotá. In Proceedings of the 10th Latin American and Caribbean Conference, (LACCEI, 2012), Panama City, Panama, 23-27 July 2012.

131. Ventilation for Non-Residential Buildings-Performance Requirements for Ventilation and Room-Conditioning Systems; EN 13779:2007; European Committee for Standardization (CEN): Brussels, Belgium, 2007.

132. Thermal Environmental Conditions for Human Occupancy; ASHRAE Standard 55-2017; American Society of Heating Refrigerating and Air-Conditioning Engineers: Atlanta, GA, USA, 2017.

133. Ergonomics of the Thermal Environment-Analytical Determination and Interpretation of Thermal Comfort Using Calculation of the PMV and PPD Indices and Local Thermal Comfort Criteria; EN ISO 7730:2005; European Committee for Standardization (CEN): Brussels, Belgium, 2005.

134. Olesen, B.W. Productivity and Indoor Air Quality; Ver de Frie: Zaprešić, Croatia, 2010; p. 19. 